\title{
IfIISGUC.ORG
}

"İȘ, GÜC̣" ENDÜSTRi ilișKKiLERI VE iNSAN KAYNAKLARI DERGISi

"IS, GUC" INDUSTRIAL RELATIONS AND HUMAN RESOURCES JOURNAL

\section{Trade Unions As Employers: The Case Of Union Experts In Turkey}

\author{
Banu UÇKAN
}

Assoc. Prof. Dr. / Anadolu University

Ekim/October 2011, Cilt/Vol: 13, Sayı/Num:4, Page: 23-42

ISSN: 1303-2860, DOI: 10.4026/1303-2860.2011.187.x

Makalenin on-line kopyasına erişmek için:

http://www.isguc.org/?p=article\&id=469\&vol=13\&num=4\&year=2011

To reach the on-line copy of article:

http://www.isguc.org/?p=article\&id=469\&vol=13\&num=4\&year=2011

Makale İçin İletişim/Correspondence to: 
(C) 2000- 2011

"İşGüç" Endüstri İlişkileri ve İnsan Kaynakları Dergisi

"İşGüç" Industrial Relations and Human Resources Journal

Ekim/October 2011, Cilt/Vol: 13, Say1/Num: 4

ISSN: 1303-2860, DOI: 10.4026/1303-2860.2011.187.x

Editör/Editor-in-Chief

Aşkın Keser (Uludă̆ University)

Editör Yardımcıları/Co-Editors

K.Ahmet Sevimli (Uludăg University)

Gözde Yllmaz (Marmara University)

Uygulama/Design

Yusuf Budak (Kocaeli Universtiy)

\author{
Yayin Kurulu / Publishing Committee \\ Dr.Zerrin Firat (Uludă̆ University) \\ Doç.Dr.Aşkın Keser (Kocaeli University) \\ Prof.Dr.Ahmet Selamoğlu (Kocaeli University) \\ Yrd.Doç.Dr.Ahmet Sevimli (Uludağ University) \\ Yrd.Doç.Dr.Abdulkadir Şenkal (Kocaeli University) \\ Yrd.Doç.Dr.Gözde Yilmaz (Kocaeli University) \\ Dr.Memet Zencirkıran (Uludağ University)
}

Uluslararası Danışma Kurulu / International Advisory Board

Prof.Dr.Ronald Burke (York University-Kanada)

Assoc.Prof.Dr.Glenn Dawes (James Cook University-Avustralya)

Prof.Dr.Jan Dul (Erasmus University-Hollanda)

Prof.Dr.Alev Efendioğlu (University of San Francisco-ABD)

Prof.Dr.Adrian Furnham (University College London-İngiltere)

Prof.Dr.Alan Geare (University of Otago- Yeni Zellanda)

Prof.Dr. Ricky Griffin (TAMU-Texas AEM University-ABD)

Assoc. Prof. Dr. Diana Lipinskiene (Kaunos University-Litvanya)

Prof.Dr.George Manning (Northern Kentucky University-ABD)

Prof. Dr. William (L.) Murray (University of San Francisco-ABD)

Prof.Dr.Mustafa Özbilgin (University of East Anglia-UK)

Assoc. Prof. Owen Stanley (James Cook University-Avustralya)

Prof.Dr.Işık Urla Zeytinoğlu (McMaster University-Kanada)

Danışma Kurulu / National Advisory Board

Prof.Dr.Yusuf Alper (Uludağ University)

Prof.Dr.Veysel Bozkurt (Uludağ University)

Prof.Dr.Toker Dereli (Işık University)

Prof.Dr.Nihat Erdoğmuş (Kocaeli University)

Prof.Dr.Ahmet Makal (Ankara University)

Prof.Dr.Ahmet Selamoğlu (Kocaeli University)

Prof.Dr.Nadir Suğur (Anadolu University)

Prof.Dr.Nursel Telman (Maltepe University)

Prof.Dr.Cavide Uyargil (İstanbul University)

Prof.Dr.Engin Yildırım (Sakarya University)

Doç.Dr.Arzu Wasti (Sabancı University)

Dergide yayınlanan yazllardaki görüşler ve bu konudaki sorumluluk yazarlarına aittir.

Yayınlanan eserlerde yer alan tüm içerik kaynak gösterilmeden kullanılamaz.

All the opinions written in articles are under responsibilities of the outhors.

None of the contents published can't be used without being cited. 


\title{
Trade Unions As Employers: The Case Of Union Experts In Turkey $^{1}$
}

\author{
Banu UÇKAN
}

Assoc. Prof. Dr. / Anadolu University

\begin{abstract}
Özet
Sendikalar, çalışanların yalnızca çalışma koşullarını iyileştirmeyi amaçlayan örgütler olarak değil, aynı zamanda işveren olarak da çalışma hayatının içinde yer almaktadır. Sendikaların ölçekleri büyüdükķ̧e ve işlevleri karmaşıklaşııkça, istihdam ettikleri ofis çalışanlarının, danışmanların ve uzmanların sayısı da artmaktadır. Bu makale, sendika uzmanlarının çalışma koşulları, sorunları, sendikalaşma eğilimleri ve sendika yöneticileri ile olan ilişkileri üzerinde odaklanarak sendika uzmanlarmın genel bir profilini çizmeyi ve sendikaların işveren rolünü değerlendirmeyi amaçlamaktadır. Diğer bir ifadeyle bu makalenin temel amacl, ücretli çalışanların çalışma koşulların iyileştirmeyi amaçlayan sendikaların, kendi çalı̧anlarımın hak ve çıkarlarını ne ölçüde koruduğunu, anket ve derinlemesine görüşme yöntemlerini kullanarak tartışmaktır.
\end{abstract}

Anahtar Kelimeler: sendika uzmanı, sendikacılık, endüstri ilişkileri

\begin{abstract}
Trade unions are not only the associations of workers for the purpose of improving the conditions of their working life, but are also one of the employers. As trade unions grew in size and complexity, the number of clerical staff, consultants and experts has been increasing. This article aims to describe a general profile of the union experts and examine the roles of trade unions as employers by focusing on working conditions, problems and unionisation trend of union experts and also the relationship between union experts and union executives in Turkey. In other words, the main objective of the paper is to discuss to what extent the unions which are continuous associations of wage earners for the purpose of improving the conditions of their working life, protect and improve their own employees' rights and interests by using both survey technique and in-depth interviews.
\end{abstract}

Keywords: union expert, trade unionism, industrial relations

1 This article is an extended version of a paper submitted to the Industrial Relations in Europe Conference (IREC) held on 8-10 September 2010 in Oslo. 
As trade unions grew in membership, geographical base, funding and complexity, their administrative structure had to be changed. Early trade unions were governed by primitive democracy which was based on direct participation of members. Since this system became not practible in years, trade unions began to be governed by representative democracy and move from less to more bureaucratic forms of administration ${ }^{2}$. So they felt need to employ professionals to meet the increasing and changing demands of members. In other words, as unions have evolved, the number of paid employees providing professional and technical assistance and clerical support has increased significantly. Particularly with the new unionism which centres on individual approach rather than traditional collectivist approach, the role of professionals at the unions gained importance. Furthermore, union experts began to be perceived as human capitals of unions. This evolution transformed the unions as employers. (Clark, 1989: 584; Kelly and Heery, 1994: 8; Snape, 1995: 559; Munro and Rainbird, 2000: 227-228; Heery, 2003: 293; Burchill, 2008: 50-51).

The Trade Unions Act no: 2821 explicitly specifies four mandatory organs of trade unions in Turkey: General congress (general assembly), management board, auditing board and disciplinary board. The one holding elected positions at these boards is called as union executive. However as labour organizations expand their scope in terms of membership and in terms of issues they address, trade unions and union executives need a significant number of professionals; such as clerical staff and experts. Besides those compulsory organs above, trade unions may establish some departments, i.e. collective bargaining, recruitment, training, international relations, research/media, according to their needs and scope; and employ some experts for these departments. One of the union executives of the management board is usually responsible for each department.
The experts are not elected as union execuitves; they are directly employed by unions. Due to their professions and specialities, the experts are generally named as the intellectuals of unions. Other professionals at the unions are clerical staff dealing with office works. Secretary, clerk, bookkeeper, data entry operator and accountant are identified as clerical staff.

However the studies related to professionals and particularly union experts who play important roles in recruiting new members and retaining current ones are enough in terms of quantity and quality neither in Turkey nor in the other countries. There are some studies on full-time officers (Clegg, Killick and Adams, 1961; Boraston, Clegg and Rimmer, 1975; Watson, 1988; Kelly and Heery, 1994), full-time paid employees (Belfer, 1952; Shair, 1970; Clark, 1989) and union professionals (Wilensky, 1956; Clark, 1992), but the union experts were either not involved or mentioned briefly in these studies. In other words, despite their importance not much is known about union experts. Likewise in Turkey, there are only two major studies which did not examine the role of union experts directly but mentioned indirectly (Dereli, 1975; Petrol-İs,, 1993). In Dereli's study, it was determined that unionization and union bureaucracy were not yet developed by 1975, and the interviews with few union experts were examined. In 1992, Petrol-İş, trade union in the petroleum, chemicals and rubber sector, published a study on the general structure and activities of trade unions. In this study, union experts working in 26 different trade unions were also analyzed by a narrow survey but the working conditions and problems of union experts were not focused in details.

Trade unions, which are not based on a class rooted social movement in Turkey, followed an easy recruitment strategy focused on public sector until recently. However as from the 1990s, privatization policy at public

2 Some of the most contentious issues on union organization, e.g. bureaucracy and oligarchy, were first highlighted in the Webbs' studies (Webbs, 1902; Webbs, 2007). 
sector diminishes the membership base of the unions ${ }^{3}$. Consequently the unions were confronted to the obligation for organizing in private sector in order to survive. Therefore, the union experts could play a key role in order to reverse the union decline both in membership and in influence. In this sense, this paper focuses first to describe a general profile of the union experts, who are usually at backstage of the unions in Turkey. Secondly, the paper covers to examine the roles of trade unions as employers by focusing on working conditions, problems and unionisation trend of union experts and also the relationship between union experts and union executives. In other words, the main objective of the paper is to discuss to what extent the unions which are "continuous association(s) of wage earners for the purpose of improving the conditions of their working life" (Webb and Webb, 1902: 1), protect and improve their own employees' rights and interests. Because of their different qualifications and working tasks, clerical staff will not be included in the study.

\section{Research Method}

In Turkey workers have rights to organize, bargain collectively and strike, whereas public servants solely have the right to organize $^{4}$. Due to the lack of rights of collective bargaining and strike, different characteris- tics, history and experiences of public servants' unions; union experts, only who are working at labour unions ${ }^{5}$, were targeted in this study. Ministry of Labour and Social Security (MLSS) declared that by July 2009 there were 94 trade unions and three labour confederations. However, only 46 of these unions have the adequate number of members that would surpass the $10 \%$ threshold required for representation in collective bargaining ${ }^{6}$. Trade unions that could not surpass the $10 \%$ threshold do not have adequate financial resources to employ experts; therefore this study covers the union experts employed in those 46 trade unions which surpassed the $10 \%$ threshold by July 2009 and the three labour confederations. The members of those 46 trade unions constitute $95.58 \%$ of all organized labour force in Turkey, which is indicates that trade unions covered in the study have the ability to represent the organized labour force.

However, the researcher faced some difficulties in determining the total population of the research study. Some of the trade unions in Turkey continue to employ former union executives (such as branch executives, board members, and etc. $)^{7}$ or family members and relatives of union executives as "experts" or sometimes as "consultants", who mostly do not actually perform any of the work tasks of experts or consultants. It

3 Union density rate is around $12-13 \%$ and collective agreements cover only 900.000 workers in Turkey. For details see: Uçkan, 2007: 108-11

4 Public servants gained the right of collective bargaining with the constitutional referendum on a number of changes to the constitution on 12 September 2010. However any related acts have not come into force yet.

5 "Trade union" will refer to "labour union" in the paper from now on.

6 Collective Labour Agreement Strike and Lock-out Act has brought two major and controversial stipulations concerning authorisation for collective bargaining: to represent at least $10 \%$ of the total number of employees in the concerned industry - the so-called $10 \%$ threshold; and to represent more than half of the total number of employees in the concerned workplace.

7 In Turkey, former union executives do not generally go back to their previous jobs as "workers" after finishing up their time in power. When workers become executives in unions, they experience a certain increase in their status and standards of living; therefore, they prefer not to go back to their lives as workers after finishing up their time in power. As a result, their privileged positions as union executives usually continue by being employed as "experts" or "consultants". While some of these experts and consultants continue to work for the unions by conveying their critical experiences, a large part of them continue working for the unions as "ATM (automated teller machine) experts or consultants". "ATM experts or consultants" refer to personnel who actually do not work as experts/consultants but paid regularly as if they worked. Their wages are usually significantly higher than that of genuine experts. 
shows a strong nepotism ${ }^{8}$ trend at trade unions in Turkey. Therefore, it was rather difficult for the researcher to determine the exact number of "genuine union experts". In order to overcome this obstacle, the researcher visited some of the trade unions herself, and tried to contact the rest by telephone or via emails. As a result of these efforts, the researcher clarified that trade unions and confederations employ approximately 200 experts, who actually and genuinely work at the different departments such as recruitment, collective bargaining, international relations and training under the subordination of union leaders and executives.

The researcher employed both survey technique and in-depth interviews in this study. The survey questionnaire consists of 37 questions about union experts' demographic characteristics, working conditions, ways of getting organized, and relations with union management, and also their opinions on the union struggle. Most of the questions are structured questions, while some of them are open-ended ones. Survey questionnaire was sent to the unions via email, however, the researcher delivered the survey questionnaire to some of the unions and confederations personally. Of the 200 union experts survey questionnaire was sent, 95 of them participated in the study. A small proportion of experts $(7.6 \%)$ performed some managerial tasks in the past. These experts that were union executives once are now working as union experts in a real sense. Therefore, it is possible to say that survey questionnaires were filled by "genuine" experts.

Some experts had concerns about participating in the study, and asked the researcher to send the questionnaire to the union executives beforehand with a cover letter explaining the aim of the study. These experts could have participated in the research study only by the consent of union executives, and the filled questionnaires were sent back to the researcher by the union itself. Therefore, the researcher believes that these experts might have responded to the questions in line with the union's expectations rather than their sincere opinions and feelings. In order to obtain information on topics that are not covered in the survey questionnaire and support the research findings, the researcher conducted five in-depth interviews with experts working in different unions. The flow of in-depth interviews consists of semi-structured questions probing the actual situation of the unions.

While preparing the survey questionnaire, the researcher planned to ask the experts for which trade union and/or at which sector they are working. However, interviews with experts before the fieldwork made the researcher realize that questions on this topic should be removed from the survey questionnaire for obtaining sincere and accurate responses from the experts. Union experts expressed their concerns about anonymity, even if they only answered questions about sector, they were still concerned of being exposed to the unions' managements. Because there is only one trade union in some of the industries such as sugar, railways, national defence. This anonymity issue illustrates the significant fact about union managements' oppressing attitude over their personnel and lack of job security of experts.

\section{Demographic Characteristics of Experts}

About $69.6 \%$ of the union experts responding the survey were males. A male dominated sample of union experts is not very surprising in Turkey. Because most of the union members and union executives are also males. Due to the limited number of female paid workers, the female union density rate is low in Turkey. Only 15\% of 3.138.120 union members were females by 2008 (MLSS, 2008: 138). Dominantly male characteristic of union membership also reflects on

8 For nepotism see: (Vinton, 1998). 
union executives. While there is no female leader in labour confederations, only 6 of the 94 union leaders and 98 of the 1078 union board members are females in Turkey by 2009 (MLSS, 2010: 118). As a consequence, trade unions are described as "middle aged male organizations". This perception also effects the gender characteristics of union experts. In this sense, male experts are employed particularly in the recruitment and training departments since they could establish rapport with workers much easier. However female experts are predominantly employed in the research, media and international relations departments. While $11.8 \%$ of the experts in recruitment department and only $8.7 \%$ of the experts in training department are female, these rates in the research/media and international departments are raising to $34.3 \%$ and $40 \%$ respectively.

About $63.5 \%$ of the experts were over the age of 35 and $41.3 \%$ of them had been working at the same trade union for over 10 years. If we take into consideration the fact that $23.9 \%$ of the experts that previously worked for a different trade union, it could be said that the experts had a considerable union experience. But some experts claim that the relationship between senior and junior experts has been weakening gradually.
According to an expert with over 20 years of union experience;

Prior to 1980 there was a master-apprentice relationship between the experts in unions while today this relationship is loosening. The unity of political views among experts is presently weakening and bureaucratic/technician experts are gaining prominence in place of missionary experts who dedicated themselves to the trade union.

When we examine the educational backgrounds of union experts, we see that almost all of them are university graduates (94.6\%). Besides, $39.1 \%$ of those university graduates had achieved a further degree like MS or $\mathrm{PhD}$. These findings show us that union experts represent the best educated personnel at the unions. Union experts with a graduate degree are coming from a wide array of disciplines, however the ratio of Department of Labour Economics and Industrial Relations graduates constitute almost one fifth $(21.8 \%)$ of the all university graduate experts. In addition, more than $40 \%$ of the union experts with a MS or PhD degree seem to prefer achieving their degrees at Labour Economics and Industrial Relations (see Table 1). Some of the union experts indicated that they star-

Table 1

University undergraduate and graduate degrees

\begin{tabular}{|c|c|c|}
\hline Program & Undergraduate (\%) & Graduate (\%) \\
\hline Business Administration & 4.6 & 11.1 \\
\hline Economics & 11.5 & 11.1 \\
\hline $\begin{array}{c}\text { Labour Economics and } \\
\text { Industrial Relations }\end{array}$ & $\mathbf{2 1 . 8}$ & $\mathbf{4 1 . 7}$ \\
\hline Public Finance & 2.3 & - \\
\hline Public Administration & 6.9 & - \\
\hline International Relations & 5.7 & 8.3 \\
\hline Sociology & 3.4 & 2.8 \\
\hline Law & 13.8 & - \\
\hline Other & $\mathbf{2 9 . 9}$ & 25.0 \\
\hline Total & $\mathbf{1 0 0}$ & $\mathbf{1 0 0}$ \\
\hline
\end{tabular}


ted to work for the unions during the graduate programs through references granted by their professors or by other union experts enrolled in the same programs. Hence, it is possible to say that especially graduate programs of universities in Ankara and Istanbul is playing a key role in creating opportunities for graduate students to work for the unions. Moreover, in recent years some of the union experts with a PhD degree did have the chance of leaving trade unions and starting a new career in universities as professors.

It is not strange that the Department of Labour Economics and Industrial Relations is so prominent in the experts' education profile. The Departments admitted their first students in $1982^{9}$. Today, there are about 20 Departments of Labour Economics and Industrial Relations which are usually under the Faculties of Economics and Administrative Sciences in Turkey. Department graduates are generally employed in human resources departments in both public and private sector, trade unions, MLSS and the Social Security Institution. But the number of department graduates working for trade unions are not satisfactory enough. Nonetheless, it is a hopeful initiative that some trade unions and confederations have begun to give priority to this department graduates when recruiting the experts.

\section{Motives for Working at Trade Unions and Methods of Finding the Job}

The most important motives of experts for working at the unions are their belief in class and labour solidarity $(73.6 \%)$ and their educational background (15.4\%) (see Table 2 ). In other words, it could be claimed that experts work at the unions not for good wor- king conditions and high wages, but for their belief in class struggle. As a consequence, most of the experts indicate that they would not accept the job offers with higher wages and better conditions from private and public sector or from employers' associations. But $40.2 \%$ of the experts indicate that they would evaluate the job offers from the unions or confederations by considering their ideology and polices (see Table 3). In this sense, it could be said that the career priorities of experts are not high wages and satisfactory working conditions, but achieving the class ideals, as shown in Table 2.

\section{Table 2}

Motives for working at the unions

\begin{tabular}{|l|c|}
\hline \multicolumn{1}{|c|}{ Motives } & $(\mathbf{( \% )}$ \\
\hline Belief in class and labour solidarity & 73.6 \\
\hline Good working conditions & 5.5 \\
\hline Not finding a better job & 4.4 \\
\hline Educational background & 15.4 \\
\hline Other & 8.8 \\
\hline
\end{tabular}

*Some respondents indicated more than one motive

Most of the experts state that they do not perceive trade unions as employers and consequently, they do not bargain even wages. These experts, characterized as "dedicated experts", do not regard their own job as an ordinary one, but regard as a part of their lives and ideals. As one of these dedicated experts stated;

Our jobs are not the kind of job where we can turn off the computer at 18:00, go home and watch TV in comfort; it is not

9 Although there was no separate department under the name of Labour Economics and Industrial Relations before 1982, social policy had been teaching at some departments and a social policy research institute was established at Istanbul University in 1933. But following the military coup in 1980, the Council of Higher Education (YÖK) was established in 1982 to bring the universities under the government control. In this process, the research institute which consisting of two sceptical words "social" and "policy" was replaced by the Department of Labour Economics and Industrial Relations. It could be claimed that some Turkish academicians who went to the USA for post-doctoral research those years were inspired from School of Industrial and Labour Relations at Cornell University ). 
Table 3

Would you accept a job offer with better pay and working conditions?

\begin{tabular}{|l|c|c|c|}
\hline \multicolumn{1}{|c|}{ Offering party } & \multicolumn{2}{|c|}{ Answers (\%) } \\
\hline & Yes & No & $\begin{array}{c}\text { I would decide by considering the } \\
\text { ideology and polices of those unions } \\
\text { and confederations }\end{array}$ \\
\hline $\begin{array}{l}\text { A company or institution in the private or } \\
\text { public sector }\end{array}$ & 30.4 & 69.6 & - \\
\hline $\begin{array}{l}\text { Trade union or public servants' union or } \\
\text { confederation }\end{array}$ & 10.9 & 48.9 & 40.2 \\
\hline Employers' association or confederation & 8.8 & 84.6 & 6.6 \\
\hline
\end{tabular}

the kind of job where we can have weekend holidays. Our jobs are just our lives...

The main criterion of experts for selfidentification also supports their motives for working at the unions. Experts identify themselves primarily by their social class $(30.4 \%)$ and their political preference $(28.3 \%)$ (see Table 4).

About $46.7 \%$ of the experts found the job through their friends. It is possible to suggest that experts already employed in the unions help their friends, who share the same political preferences and class beliefs, to find a job in the unions. Roughly $14.3 \%$ of the experts found the job by themselves through newspaper advertisements or inter-

Table 4

\section{Criterion for self-identification}

\begin{tabular}{|l|c|}
\hline \multicolumn{1}{|c|}{ Identity } & (\%) \\
\hline Nationality & 9.8 \\
\hline Religion & 2.2 \\
\hline Social class & 30.4 \\
\hline Gender & 5.4 \\
\hline Profession & 12.0 \\
\hline Workplace & 1.1 \\
\hline Political preference & 28.3 \\
\hline Other & 10.9 \\
\hline Total & 100 \\
\hline
\end{tabular}

net and etc., while $23.9 \%$ of them found the job through other methods (reference of professors at the universities, received job offers from unions etc.) (see Table 5).

Although only $14.2 \%$ of the experts found the job through relatives (see Table 5), it could be assumed that this percentage would increase significantly if all union experts, including the ATM experts, were taken into consideration. The statement below of a "genuine" expert is striking enough;

I have been working at this union for 20 years and I thought I was the unique expert employed here. At the latest general congress, I learned that there are four more experts employed here, but I have not seen any of them here at the union.

This is also one of the examples showing the way of squandering the union fees and

\section{Table 5}

The methods of finding the job

\begin{tabular}{|c|c|}
\hline Method & $(\mathbf{\%})$ \\
\hline $\begin{array}{c}\text { Self effort } \\
\text { (Newspaper adverti- } \\
\text { sement, internet, etc) }\end{array}$ & 14.2 \\
\hline Through relatives & 14.3 \\
\hline Through friends & 47.3 \\
\hline Other & 24.2 \\
\hline
\end{tabular}


inadequate auditing system. Another expert summarizes below the precondition for getting a job at the union:

For working as an expert in trade unions, you either have to be indispensable in your field or a close relative of the union leader.

It is a recent trend that some unions and confederations have began to recruit experts through private employment agencies. It has two significant aspects. First, trade unions and confederations ideologically opposed to private employment agencies and lobbied the President to veto the act regulating temporary work agencies in 2009. Therefore the recruitment of experts through private employment agencies by unions is rather contradictory. Secondly, even though these agencies could be an appropriate means for recruiting clerical staff in unions, this method is not proper for recruiting experts. As mentioned before, one of the most important characteristics of union experts is strong class awareness and belief. It is almost impossible to be a "dedicated expert" without this characteristic. Therefore recruiting experts through private employment agencies could be analyzed as a proof of union desire for employing technician/bureaucrat experts rather than the dedicated/missionary ones.

It could be suggested that improving the internship opportunities at the unions to students at the Departments of Labour Economics and Industrial Relations would be used for prospective recruitment. Although the internship opportunities providing by the unions have been increasing recently, they are not satisfactory enough in terms of quantity or quality. Only $19.6 \%$ of the union experts had interned at a union before being employed. If the internship would be used efficiently, unions could find a chance to recruit more proper staff and the students, who are planning to work at the union after graduated, could have an opportunity to insight the union activities and policies.

\section{Union Departments and Individual Work Tasks}

Unions and union confederations form various departments with respect to their sizes and relative significance they attribute to organizational activities, and accordingly they employ a varying number of union experts in these departments. Unions and confederations employ experts mainly in departments such as recruitment, collective bargaining, training, legal affairs, research/media and international relations (see Table 6).

\section{Table 6}

\section{Union departments}

\begin{tabular}{|c|c|}
\hline Departments & (\%) \\
\hline Recruitment & 18.5 \\
\hline Collective bargaining & 22.8 \\
\hline Training & 25.0 \\
\hline Research/media & 38.0 \\
\hline Legal affairs & 7.6 \\
\hline International relations & 21.7 \\
\hline Other & 13.0 \\
\hline
\end{tabular}

* Some experts indicated more than one department

Of the 95 union experts responding to the survey, $25 \%$ works at more than one department. This finding illustrates that some of the trade unions do not employ sufficient number of experts. MLSS declared that 3.232.679 workers are members of trade unions by July 2009 . On the other hand, approximately 200 union experts are employed by unions to serve to this huge amount of workers, which produces a ratio of merely one expert serving to 160.000 members. Parallel to these facts, $59.8 \%$ of the union experts participating in the study believe that unions in Turkey do not employ adequate number of experts in their organizations. Deficiencies in the financial positions of unions (34.5\%) 
and unions' lack of realizing the importance of employing experts (34.5\%) are specified as the main reasons behind this insufficiency. Issues about unions' sizes and lack of institutionalisation are declared as the second important reason, where lack of skilled union experts is put forward as another explanation for not employing sufficient number of experts at the unions (see Table 7).

Since 1980's, the balance of power in industrial relations had shifted in favour of employers rather than unions as a consequence of experiences like 1982 Constitution and other legislative regulations that came into effect after the 1980 military coup, employers' policies against unions and union members, and implementation of neo-liberal policies that had reshaped the economic environment. At the same time, unions, which traditionally organize public sector, started to lose power with privatisation acts that were implemented in line with neo-liberal policies. Moreover, rapidly losing members in recent years became another concern that affects unions in a negative fashion, which also produce a damaging impact on their financial structures. Thus, some of the unions employ insufficient numbers of experts while others do not employ experts at all, which could be claimed as the expected outcome of the above mentioned practices. The rapid pace of losing members, as some experts believe, would make unions unable to finance overhead costs in five years time. On the other hand, unions try to economize by employing lesser number 'genuine experts' than it is needed while persist on paying high amounts of wages and pensions to union leaders, execuitves and 'ATM experts and consultants' despite their distorted financial structures, which in fact poses another important issue about the functioning of unions in Turkey. One of the interviewed experts remarked an interesting point on this topic;

Trade unions in Turkey value two departments more than the others: Accounting and legal affairs. Accounting is valued because this department collects membership fees. Legal affairs has a significant weight since every dispute regarding industrial relations and union struggle is resolved in courts. The other departments are accessories or gimmicks of unions...

Table 7

The reasons underlying insufficient employment of experts in unions

\begin{tabular}{|c|c|c|c|}
\hline Reasons & $\begin{array}{c}\text { Main } \\
\text { reason } \\
\%\end{array}$ & $\begin{array}{c}\text { Second } \\
\text { reason } \\
\%\end{array}$ & $\begin{array}{c}\text { Third } \\
\text { reason } \\
\%\end{array}$ \\
\hline Lack of realizing the need for union experts & 34.5 & 14.3 & 11.1 \\
\hline Deficiencies in the financial positions of unions & 34.5 & 6.1 & 15.6 \\
\hline Undersized unions and lack of institutionalisation & 10.9 & 44.9 & 22.2 \\
\hline Lack of skilled union experts & 3.6 & 8.2 & 24.4 \\
\hline Political and bureaucratic concerns of executives & 9.1 & 18.4 & 8.9 \\
\hline Unions' reliance on government rather than struggle & 3.6. & 8.2 & 13.3. \\
\hline Unions' activities not requiring employing experts & - & - & 2.2 \\
\hline Other & 3.6 & - & 2.2 \\
\hline Total & 100 & 100 & 100 \\
\hline
\end{tabular}


Union experts, who responded to the survey, perform the following work tasks at relevant departments in order of importance (see Table 8): collective bargaining, training, research/reporting, and preparing press releases and speeches for the union or the president. The most important function of trade unions in Turkey is collective bargaining as it is in all other countries. Therefore, it is obvious that union experts' most important work task is organizing preliminary stages of and conducting collective bargaining. Recruitment comes out to be another important work task for union experts. We can observe that trade unions utilise union experts for recruitment at a lesser degree in recent years. One of the interviewed experts expressed a significant comment on the topic as;

Union experts are ruptured from labour class by being withdrawn from organization and member recruitment activities. Before 1980 union experts spent 5-6 months in the field organizing workers and establishing organic bonds with the labour class, but after 1980 the relation of experts with unions changed significantly. Union executives employ experts only for preparing press releases, research, and etc. Branch executives are assigned for organization and field work. Anyway, unions no longer go to workers to organize them; workers come to unions to get organized recently...

After collective bargaining, the other important work tasks of union experts come out to be training and research/reporting. According to the Trade Unions Act no.2821, trade unions and confederations should allocate at least $10 \%$ of their revenues for training programs designated for their members. Therefore, trade unions and confederations conduct training programs on a wide array of topics from working life to political and economic issues like democracy, human rights and privatisation for their members, representatives and executives. Some of these training programs are carried out by professors from various universities while others are conducted by union experts. In recent years unions specified research/reporting and publication as other areas of significance. Thus, unions and confederations started to publish journals/magazines, newspapers, bulletins and

\section{Table 7}

The reasons underlying insufficient employment of experts in unions

\begin{tabular}{|l|c|c|c|}
\hline Task & $\begin{array}{c}\text { Most important } \\
\text { task } \\
\mathbf{( \% )}\end{array}$ & $\begin{array}{c}\text { 2nd important } \\
\text { task } \\
\mathbf{( \% )}\end{array}$ & $\begin{array}{c}\text { 3rd important } \\
\text { task } \\
\mathbf{( \% )}\end{array}$ \\
\hline Recruitment & 14.1 & 9.2 & 3.8 \\
\hline Training & 13.0 & $\mathbf{1 9 . 5}$ & 13.8 \\
\hline Collective bargaining & $\mathbf{1 8 . 5}$ & 6.9 & 1.3 \\
\hline Legal representation at courts & 8.7 & - & 2.5 \\
\hline Coordinating publications & 10.9 & 12.6 & 7.5 \\
\hline Developing policies and strategies & 3.3 & 13.8 & 18.8 \\
\hline Preparing press releases and speeches & 2.2 & 14.9 & $\mathbf{2 1 . 3}$ \\
\hline International relations & 14.1 & - & 5.0 \\
\hline Research and reporting & 9.8 & $\mathbf{1 9 . 5}$ & 20.0 \\
\hline Other & 5.4 & 3.4 & 6.3 \\
\hline Total & $\mathbf{1 0 0}$ & $\mathbf{1 0 0}$ & $\mathbf{1 0 0}$ \\
\hline
\end{tabular}


miscellaneous reports on working life in order to inform their members and the public. Unions outsource a part of these research projects and publications while the rest is carried out by union experts. Experts perform another important work task at the unions: preparing the press releases and speeches of the unions/leaders. Union experts are responsible for preparing the speeches of the unions' leaders or press releases on any relevant topic. As one expert puts it;

Union president do not spend time for preparing press releases or writing speeches. They think that 'educated' (union) experts would write better than they do. The president could call and ask you to write a speech for the 'women's day' in a couple of hours...

All union experts accept this as an ordinary work task. Another expert comments on the topic as;

Experts are specialized on preparing joint and anonymous texts.

Besides performing above mentioned work tasks, $48.4 \%$ of the union experts represent their unions or confederations in various activities, commissions and institutions like EU projects, Minimum Wage Commission, Social Security Institution and international union meetings.

In summary, union experts do not presented a clear definition of their work tasks in Turkey. They bear a heavy workload because of insufficient number of experts and administrative staff employed at unions. Yücesan-Özdemir (2009:73) quoted an expert's comment on the topic as;

No one in labour unions, either the experts, secretaries or attendants, even gatekeepers do not perform only one work task. There should not be a 'this is not my job' kind of attitude. After all, it is all about functioning of the union. Somebody should do the job, should not let go loose. I mean, unions continue functioning upon individual sacrifices. I am not saying that this only prevails in our union, in many unions I see individual efforts stand out. I mean, if anything gets done, if something solid achieved step by step, it all depends on individual efforts...

\section{Experts' Relations with Union Management}

The relationship between union experts (who are well-educated and employed in unions for professional purposes) and elected union executives (who once were workers) has always been a critical topic of the discussions about organizational structures of trade unions. More than half of the union experts participated in the research believe that they established a harmonious (well-balanced) relation with union management. They indicate that their tasks are valued by the management and the union leaders consult them before making any important decision (see Table 9).

Then again, one of the most important aspects of the relationship of experts with union management is the experience and

\section{Table 9}

\section{The experts' relations with union leader and management}

\begin{tabular}{|l|c|}
\hline Style of Relationship & (\%) \\
\hline $\begin{array}{l}\text { There is a conflicting relationship } \\
\text { between experts and union leaders } \\
\text { and management }\end{array}$ & 6.7 \\
\hline $\begin{array}{l}\text { There is a harmonious (well-balan- } \\
\text { ced) relationship between experts } \\
\text { and union leaders and management. } \\
\text { Experts are respected, their opinions } \\
\text { and suggestions are considered }\end{array}$ & 57.8 \\
\hline $\begin{array}{l}\text { Union leader and management re- } \\
\text { gard the experts as personnel that di- } \\
\text { rectly perform under their authority; } \\
\text { experts only perform tasks assigned } \\
\text { to them }\end{array}$ & 21.1 \\
\hline Other & 14.4 \\
\hline Total & 100 \\
\hline
\end{tabular}


commitment of experts. One of the experts stated on the topic that;

Even though sometimes conflicts arise between experienced and committed experts and union management, the union management would admire the performances of these experts and take their suggestions into consideration. What is important about what you do is to 'become indispensible'...

However, experts also expressed that they are usually obliged to establish harmonious relations with union management because they are not allowed to be in a position to keep their jobs. The opinions of two experts on this issue are as follows;

Union managements want 'clerk type' experts who would obey them without questioning. Increasing number of this type of obedient experts in recent years makes the working conditions of experts' with class solidarity harder. For instance, I became accustomed to hearing a 'warning' from the management: 'is there anyone left in the unions like you who always objects and criticize'...

Most of the experts do not want to disagree with the management because they want to keep their jobs. If they are laid off, they would not have a real opportunity again, since there are very limited alternatives for them outside unions. For a former union expert it is almost impossible to find job in the private sector since no employer wants to hire them...

When the autonomy of experts in their work areas is examined, it is detected that more than half of them is dependent on union management (see Table 10). Union leaders usually prefer to be fully in charge of functioning and would restrict experts in terms of taking initiatives, or even not allow experts to take initiative. As Robert Michels' Iron Law of Oligarchy states, over the time union leaders would attempt to maximize their own interests, not that of members of the union. By holding the power and autho- rity, union managements increasingly strive for being the ultimate ruling power through expanding their domain of authority. Union leaders establish their own bureaucratic rules and solidify their power and authority in a short time. While doing this, they want union experts to work with them for solidifying their power. As one of the experts stated;

Instead of acting upon medium and long term objectives, the union leaders start to work to consolidate their power for the next term as soon as they are elected. Therefore, union leaders do not want experts to work for medium and long term objectives, but work for making them reelected in the next general congress. Experts suggest on 'what ought to be', but union leaders evaluate their suggestions according to the question 'will this suggestion reinforce my position?'...

Table 10

The level of dependence of experts to union management

\begin{tabular}{|l|c|}
\hline \multicolumn{1}{|c|}{ Level of Dependence } & (\%) \\
\hline Fully independent & 6.5. \\
\hline $\begin{array}{l}\text { Dependent on union leader and/or } \\
\text { union general secretary and/or mem- } \\
\text { bers of the board }\end{array}$ & 55.4 \\
\hline $\begin{array}{l}\text { Dependent upon management in de- } \\
\text { termining objectives and policies re- } \\
\text { garding the union but independent } \\
\text { in determining the strategies and to } \\
\text { be employed }\end{array}$ & 30.4 \\
\hline Other & $\mathbf{1 0 0}$ \\
\hline Total & \\
\hline
\end{tabular}

The following statement of an union expert who had worked as a lawyer for many years is especially striking for illustrating the experts' level of dependence on union management (FES, 1999:123);

Union leaders and managements are 
very rigid and demanding; they inflict a very strict chain of command. 'This is our notion of unions; you should support this notion with legitimate justifications'; whenever there is an internal conflict in the union, you are forced to set aside law and justify, in fact even create justice in order to support union's management. When I get angry with a friend, I say; 'May the God makes you a headquarter's lawyer during the internal conflicts!'. I deem no other punishment is larger than this...

\section{Working Conditions}

According to the union constitutions, the central executive boards which have the power to employ union staff, usually determine their working conditions and wages, as well. Consequently, the working conditions and wages of $56.5 \%$ of the experts were determined by the central executive boards (see Table 11). Therefore the working conditions of experts have been effected by the changes to the central executive board. Furthermore, when the members of central executive board change, some experts, who were in close relations with the previous board, might be dismissed and replaced by the newly employed experts, as is the case in the Turkish public bureaucracy.

The workplace problems of experts are quite different than the problems of workers in the private or public sector. Incompatibility between individual ideals and union practices is the most important problems of

\section{Table 11}

\section{Ways of determining wages and working conditions}

\begin{tabular}{|l|c|}
\hline \multicolumn{1}{|c|}{ Level of Dependence } & $\mathbf{( \% )}$ \\
\hline By collective agreement & 21.7 \\
\hline By employment contract & 7.6 \\
\hline By the decision of general congress & 5.4 \\
\hline $\begin{array}{l}\text { By the decision of central executive } \\
\text { board }\end{array}$ & 56.5 \\
\hline Others & 8.7 \\
\hline Total & $\mathbf{1 0 0}$ \\
\hline
\end{tabular}

experts. Besides, it is interesting that second and third important problems are also the same (see Table 12). The experts, who generally work at the unions for class solidarity, believe that the long-term goal of unions should be to increase the organized power of working class. Nevertheless, most of the experts felt disappointed as soon as they began to work, since they realize that the actual union practices do not meet their beliefs on unions and class solidarity. The main reason of this disappointment is the lack or failure of union democracy. The union executives alienate from members and workers soon and intend to improve their own interests instead of members', as Robert Michels' Iron Law of Oligarchy defines. One of the experts states that;

Just think about an auto repair shop. The shop owner might observe and able to solve the problems of his workers, if he lays down the cars and work together with his workers. However, if the shop owner builds a comfortable office at the second floor of the repair shop and tries to organize the work from his office, he gets further away from the problems of his workers. This is very similar to the union management. The workers, who become union executives, get further away from his membership past, and usually do not struggle for the rights of workers but for strengthening his own interests and status.

Briefly, incompatibility between individual ideals and union practices paves the way for burn-out of union experts. However, the dedicated experts are still fighting for realizing their individual ideals at the unions.

Due to the lack of skilled experts in most of the unions, experts have over workloads and no exact job and task definition. Therefore, lack of exact job definition, over workload, and long working hours are among the most important workplace problems (see Table 12). Another significant problem declared during the interviews is the lack of job security. The experts concern to be dismis- 
Table 12

Workplace problems (by order of priority \%)

\begin{tabular}{|l|c|c|c|}
\hline \multicolumn{1}{|c|}{ Problem } & $\begin{array}{c}\text { Most important } \\
\text { problem }\end{array}$ & $\begin{array}{c}\text { 2nd impor- } \\
\text { tant problem }\end{array}$ & $\begin{array}{c}\text { 3rd important } \\
\text { problem }\end{array}$ \\
\hline Unsatisfactory wages & 8.9 & 1.5 & 11.9 \\
\hline Long working hours & 7.6 & 22.7 & 6.8 \\
\hline $\begin{array}{l}\text { Lack of communication with union executives and } \\
\text { leader }\end{array}$ & 5.1 & 3.0 & 10.2 \\
\hline Poor union democracy & 11.4 & 9.1 & 11.9 \\
\hline Lack of job security & 7.6 & 4.5 & 6.8 \\
\hline Over workload & 11.4 & 4.5 & 5.1 \\
\hline $\begin{array}{l}\text { Reconciliation of demands of members and } \\
\text { executives }\end{array}$ & 1.3 & 7.6 & 1.7 \\
\hline $\begin{array}{l}\text { The irrelevant demands of members, union } \\
\text { executives and leader }\end{array}$ & 2.5 & 9.1 & 13.6 \\
\hline Lack of exact job definitions & 15.2 & 12.1 & 6.8 \\
\hline $\begin{array}{l}\text { Incompatibility between individual ideals and } \\
\text { practices }\end{array}$ & $\mathbf{2 4 . 1}$ & $\mathbf{2 4 . 2}$ & $\mathbf{1 5 . 3}$ \\
\hline Forced to take part in the struggle within the union & 1.3 & 1.5 & 10.2 \\
\hline Others & 3.8 & $\mathbf{- 1 0}$ & - \\
\hline Total & $\mathbf{1 0 0}$ & $\mathbf{1 0 0}$ & $\mathbf{1 0 0}$ \\
\hline
\end{tabular}

sed if they experience any conflict with union leader and executives; hence, they have to establish a good relationship with the union management. As a consequence, poor job security might force some experts to become passive individuals in the unions.

About $14 \%$ of the experts participating in the study did not answer the question related to workplace problems. It was considered that some of these experts did not experience any problem at the workplace. However, it was also considered that some of those experts hesitated to answer this question since they thought that the union executives could read their answers.

In the questionnaire, there is an openended question about how the experts' working conditions can be improved. Considerable number of the experts believed that the working conditions can be improved through organizing. However, it is paradoxical that only $30.8 \%$ of the experts are union members. The finding is fairly ironic that most of the experts, who work for organizing workers, are unorganized. The most specific reason for not being a union member is that experts do not perceive the unions as employers (see Table 13). In other words, since the experts do not accept themselves as workers, they do not see the unions as employers. However, most of the trade unions have typical employer's behaviours and attitudes. For instance, the experts are working too long including the weekends with heavy workloads; overtime wages are generally not paid; in case of any conflict with union executives, they can be dismissed easily; furthermore, some unions even apply union-busting strategies to their staff 
who try to organize. One of the experts similitudes that;

Slaves do not try to be freed from slavery; they just try to find new slaves for themselves.

Table 13

Reasons for not being a union member

\begin{tabular}{|l|c|}
\hline \multicolumn{1}{|c|}{ Reason } & (\%) \\
\hline I do not trust the unions & 1.6 \\
\hline $\begin{array}{l}\text { My current situation at the } \\
\text { workplace do not change with } \\
\text { membership }\end{array}$ & 6.6 \\
\hline $\begin{array}{l}\text { Employers' pressures (dismissal, and } \\
\text { threat, etc.) }\end{array}$ & 6.6 \\
\hline $\begin{array}{l}\text { I prefer to solve the problems with } \\
\text { my employer directly }\end{array}$ & 4.9 \\
\hline $\begin{array}{l}\text { The current unions do not meet my } \\
\text { expectations }\end{array}$ & 16.4 \\
\hline $\begin{array}{l}\text { I do not perceive the union as an } \\
\text { employer due to my class belief }\end{array}$ & $\mathbf{2 6 . 2}$ \\
\hline Others & 37.7 \\
\hline Total & $\mathbf{1 0 0}$ \\
\hline
\end{tabular}

In spite of all these negative working conditions, the main reason for not being a union member is that experts see themselves as missioners, not as ordinary workers. Therefore, it could be claimed that the dedication and commitments of experts to class solidarity and belief are exploited by trade unions.

It was a taboo for the experts even to talk about getting organized, but nowadays the experts have realized the necessity of organizing. An expert who is not a union member explained that;

It is necessary to apply what we teach our members during trainings to our lives. When the members asked me "ok, are you a union member?" or "why, not?" I did not know how to answer.

Second reason for not being a union member is that current unions do not meet experts' expectations (see Table 13). Some experts suggested that a guild would be more effective rather than a trade union, since the working conditions and problems of experts are fairly different from other office workers. Besides, most of the experts believe that trade unions do not have a capacity to defend and improve their rights and interests sufficiently. Therefore, some experts expressed that they would start an initiative to establish their own guild soon. The communication network that experts set up on the internet could be accepted as a first step of this initiative. Through this communication network, the experts could share workplace problems and information and also discuss different issues ${ }^{10}$. The network has already created cyber solidarity among experts.

\section{Conclusion}

The role of unions as employers which is one of the most important issues concerned with union management has virtually been ignored in the industrial relations literature. Therefore, there is not enough qualified study on the working conditions and problems of the experts who remain at the offstage and who could be called as "invisible heroes". The experts, who work devotedly and with solidarity conscious, play important roles at the unions. However, due to the lack of union democracy, the experts are pushed to the backstage of unions.

While the experts work at the unions to protect and improve the rights and interests of workers, they mostly forget that they are also workers according to the Labour Act. However, their commitments and awareness on class solidarity are usually exploited

10 Majority of the questionnaire was sent to the experts through this communication network. 
by trade unions. In other words, when the trade unions sit at the other side of the table as employers, they tend to behave like typically an employer. Thus, it could be claimed that most of the trade unions apply flexibility principle to their personnel under the cover of solidarity spirit in Turkey. Actually, trade unions apply almost all types of flexibility, such as pay flexibility, numerical flexibility, functional flexibility and working time flexibility to their experts. In this sense, getting organized is crucial for experts in order to solve their common workplace problems. However, it is believed that instead of unionization, experts should be organized under guilds since their numbers are limited and working conditions are rather specific.

The centralized structure of trade unions paves the way for passive experts, the experts cannot use initiative enough. However, the unions, which lost a significant ground in recent days, should employ qualified experts who are described as "organic intellectuals" and give them initiative in order to reverse this process. The qualifications of experts should be the major recruitment criteria instead of recruiting them with reference to their family and friendship relations. Therefore trade unions should cooperate with universities rather than employing the experts through private employment agencies, and the internship opportunities for university students should be developed. Employing qualified experts and giving them initiatives should not be perceived as a threat by the union executives. In other words, experts should be regarded as the most important human resources of the unions, not as rivals of executives or professionals limiting the union executives' power. Providing opportunities to the experts to transfer their educational background and experience to union struggle freely would help the unions for gaining strength and institutionalizing as well as for developing union democracy.

\section{References}

Belfer N (May 1952) Personnel practices in trade unions. Personnel: 442-446.

Boraston I, Clegg HA and Rimmer M (1975) Workplace and Union. London: Heinemann.

Burchill F (2008) Labour Relations. New York: Palgrave Macmillan.

Clark P (July 1989) Organizing the organizers: professional staff unionism in the American labor movement. Industrial and Labor Relations Review 42(4): 584599.

Clark P (Fall 1992) Professional staff in American unions : changes, trends, implication. Journal of Labor Research. 8(4): 381-392.

Clegg HA, Killick AJ and Adams R (1961) Trade Union Officers. Oxford: Blackwell.

Dereli T (1975) Aydınlar, Sendika Hareketi ve Endüstriyel İlişkiler Sistemi. İstanbul: Fakülteler Matbaası.

Friedrich Ebert Stiftung (FES) (1999) Sendikal Eğitim Atölye Çalışmaları. İstanbul: Türkiye Ekonomik ve Toplumsal Tarih Vakfi.

Heery E (2003) Trade unions and industrial relations. In: Ackers P and Kelly J (eds) Understanding Work\&Employment. Oxford: Oxford University Press: 278304.

Heery E and Kelly J (March 1994) Professional, participative and managerial unionism: an interpretation of change in trade unions. Work, Employment and Society 8(1): 1-22.

Kelly J and Heery E (1994) Working for the union. Cambridge: Cambridge University Press. 
Ministry of Labour and Social Security (MLSS) (2008) Labour statistics 2007. Ankara: Directorate-General of Labour Publication No: 33.

Munro A and Rainbird H (2000) The new unionism and the new bargaining agenda: UNISON-employer partnerships on workplace learning in Britain. British Journal of Industrial Relations 38(2): 223-240.

Petrol-İşs (1993) Sendikalar-YapılarıÇalışmaları. Istanbul: Petrol-İş Yayın: 29.

Shair DI (July 1970) Labor organizations as employers: 'unions within unions'. Journal of Business 43: 296-316.

Snape E (September 1995) The development of 'managerial unionism' in Britian: a research note. Work, Employment Society 9(3): 559-568.

Uçkan B (2007) From the perspective of EU integration: trade union rights in Turkey. SouthEast Europe Review for Labour and Social Affairs 4: 107-126.

Vinton KL (1998) Nepotism:An interdiciplinary model. Family Business Review. 11(4): 297-303.

Watson D (1988) Managers of Discontent: Trade Union Officers and Industrial Relations Managers. London: Routledge.

Webb S and Webb B (1902) Industrial Democracy. London: Longsman Green.

Webb S and Webb B (2007) The History of Trade Unionism (1920). Montana: Kessinger Publishing

Wilensky, H (1956) Intellectuals in the Labor Movement. Glencoe: The Free Press,

Yücesan-Özdemir G (2009) Emek ve Teknoloji. Ankara: Tan Kitabevi.
MLSS. (2008). http:/ / www.csgb.gov.tr/articles.php?category_id=50 (accessed on July 19, 2010)

MLSS.(2010)http:/ /www.csgb.gov.tr/csgbP ortal/ShowProperty/WLP\%20Repository / csgb/dosyalar/istatistikler/calisma_hayati_2009 (accessed on July 3, 2011)

\section{Acknowledgment}

I would like to thank to Murat Özveri, Aziz Çelik, Hakan Koçak and İçlem Er for their support during the research. 
